\title{
FERTILITY CULT IN ANCIENT UGARIT E. Lipiński
}

The sacred marriage is likely to have been one of the main manifestations of the fertility cult in Ugarit as well as in other regions of the ancient Near East. Our written Ugaritic sources go back to the Late Bronze age, mainly to the 14 th and 13 th centuries B.C., but the myth and the ritual embodied in the text we are going to examine must be more ancient. In fact, the god El plays the vital role in it, while the god Baal is not even mentioned.

Basing themselves on this mythological and ritual text, known as the Poem in honour of the gods Shachar and Shalim, or Poem on the Gracious Gods $(K T U 23=C T A 23)^{1}$, some authors assume that the rite of the sacred marriage was performed by the king at the close of the New Year festivities constituting the feast of first-fruits. Accordingly, the concerned text would be the libretto of a cultic play or "ritual pantomime"2, in which the roles of the Head of the Pantheon, the god El, and of his wife, the goddess Atirat, were played by the king and the queen of Ugarit.

Apparently, the first part of the text refers to the preparatory rites performed before the sacred marriage took place. Horizontal lines drawn across the tablet divide the text, separating hymnal and mythological passages from rubrical parts which contained directions of a liturgical or ritual character. The absence of any evident connection between the poetical and the rubrical sections constitutes the main difficulty for the interpretation of this part of the text.

The second part of the composition (lines 30-76) contain the narrative account of the conception and birth of two successive groups of divine children, viz. of Shachar and Shalim, who are essentially astral deities, and of the so-called "gracious gods". At the beginning of this narrative, the supreme god El, who lived "at the sources of the rivers, amidst the springs of the two oceans"3, went out to "the chasm of the sea and advanced to the chasm of the ocean"4, and saw there two girls or young women moving up and down, next to a basin. When a girl moved upwards, the other one moved downwards in a rocking motion, as if they stood at each extremity of a board balanced on a central support, and made each other go up and down alternatively. This seesaw movement does not seem to have been simply a game, for it took place next to a high basin and aimed at reaching its top. 
The chasm, next to which the events narrated in the text took place, is called gôpu in Ugaritic, ${ }^{5}$ and the expression is attested also in Greek literature; $\chi \alpha \alpha \mu \alpha \alpha \varepsilon \lambda \dot{\gamma} \varepsilon \circ \sigma$, "the chasm of the sea". 6 Gôpu could be compared to the chasm seen by Lucian under the temple of Hierapolis. According to the aetiological legend reported by him, all the water of the deluge had run down this chasm, and this event was commemorated twice a year through the rite of hydrophory: water from the sea - probably the Euphrates - was brought to the temple and poured into the chasm. ${ }^{7}$ A ceremony similar to this one, also commemorating the great flood, took place at the precinct of the Olympian Earth in Athens. Pausanias relates having seen there a cleft in the ground, a cubit in width, and says he was told by the guides that the waters of the deluge had run down that cleft. ${ }^{8}$ Since the festival recalling this event was called ispopop $\left\{\alpha^{9}\right.$. the Festival of Waterbearıng, we can assume that water was poured down the cleft into the ground to slake the thirst of the ghosts dwelling in the nether world. ${ }^{10}$ According to Plutarch, ${ }^{11}$ the festival took place at the new moon, during the month of Anthesterion, i.e. in February-March. ${ }^{12}$ A similar ceremony took place in the postexilic temple of Jerusalem. There, the rite of water pouring was performed during the full moon of Tishri, i.e. in September-October, on the opening day of the great vintage feast, now called the Feast of Sukkoth or of the Tabernacles. ${ }^{13}$

The rite of water pouring is the primitive ritual for rain. It is a common custom all over the world among primitive peoples for the 'rain-makers' to induce rain imitating the falling rain, either by sprinkling water or by pouring it into the ground. Frazer gave numerous instances from various countries, including European ones. ${ }^{14}$ For example, we read of naked women and girls from the Russian village of Ploska who poured water into the ground at night, all along the boundaries of their village. These practices aimed at obtaining the rainfall, of which the people were in such dire need, by simulating the falling rain.

Thus, if we apply ethnography to the Ugaritic text under examination, we can assume that the two young women seen by $\mathrm{El}$ were neither performing their ablutions over the basin, as some authors surmise, nor washing their clothes, as others suppose; they were simply accomplishing the final rite of hydrophory and pouring into the basin the water brought from the sea, the river or the spring.

This basin is designated by the term 'agannu, both in the passage we are interested in, and in a rubrical section of the first part of the text, prescribing to incense the basin seven times (line 15). 
This 'agannu or basin is likely to have been made out of copper, bronze or stone and to have been situated in the precinct of the temple, as a symbol of the sea. One could refer to the "sea of cast metal", placed in the temple of Solomon (I Kings 7,23-26) ${ }^{15}$, or to the colossal stone basin from Amathus in Cyprus, now in the Louvre (AO 22897), which measures $3.19 \mathrm{~m}$ in diameter and is $1.87 \mathrm{~m}$ high, with four false handles in relief encircling bull figures ${ }^{16}$. The original location of this basin and large fragments of a similar one, preserved up to $1.49 \mathrm{~m}$ in height, were found in 1976 on the acropolis of Amathus, near the main entrance of the temple dedicated to $\mathbb{R} v \pi \rho i \alpha$, the great Cypriot goddess assimilated to Aphrodite. ${ }^{17}$ There is no doubt, therefore, that these basins had a cultic function. According to II Chron. 4,6, the "bronze sea" of the Solomonic temple was used for the priests' ablutions, but being over $2.50 \mathrm{~m}$ high, it must have been very unpractical for this purpose.

It is true that a staircase flanks a miniature basin similar to the one of Amathus and kept also in the Louvre (MNB 96) ${ }^{18}$. The question is whether the staircase was intended to enable priests to perform ritual ablutions over the water-holder or to make the temple servants' task of pouring water into the basin easier. An element of the answer may be provided by a smaller vessel, $2.13 \mathrm{~m}$ wide and $0.41 \mathrm{~m}$ high, found by Cesnola next to the eastern entrance of the temple of Golgoi, also on Cyprus ${ }^{19}$. Although this basin was already broken at the moment of its discovery, it was possible to ascertain that its bottom was perforated by a hole measuring $5 \mathrm{~cm}$ in diameter. This hole may have some connection with the rite of water pouring and slaking the thirst of the earth, as reported by Pausanias. In any case, the Solomonic "bronze sea" and the Amathus basin in the Musée du Louvre must be related to the fertility cult, as strongly suggested by the symbolic meaning of the twelve oxen sustaining the "sea" and of the bulls sculptured on the four handles of the Amathus basin. With regard to this symbolism and to the religious meaning of a cultic water-holder one could also quote a smaller Syrian vessel flanked by two bulls ${ }^{20}$, as well as a scene represented on an unpublished Sidonian sarcophagus kept in the Museum of Istanbul. This scene figures two women standing at the sides of a large vessel in a ritual attitude which has been described as the "worshipping of the fertilizing water" 1 .

Considering the cultic implications of the objects described, the "sea" or 'agannu of our Ugaritic text must have had a similar symbolic significance, as the story itself would seem to suggest ${ }^{22}$. The women mentioned in it are called mušta'lûtâm or mušta'allûtâm la-ri’ši 
'aganni, literally "those raising themselves as high as the top of the basin". This meaning results from the parallel use of the expression in an Amarna letter in which Tušratta, king of Mitanni, reminds Akhenaton of the rich bridal gifts sent by Amenophis III, and which "reached as high as heaven and earth"., šamê u erșeta uštelli ${ }^{23}$. Other translations suggested for the Ugaritian expression do not have any philological basis ${ }^{24}$ and neglect an essential point of the narrative, viz. that the two women mentioned in the text were filling the "sea" of the temple 25 .

The relationship of these women with the sea is confirmed by the 'surnames' 'agzr ym and bn ym, something like "progeny of the sea" and "children of the sea", by which the children to be conceived from E1 will be called. We assume, in this case, that 'agzr is identical with the Hurrian term (d) $a-g a-a s ̌-s ̌ a-r i$, a divine epithet ${ }^{26}$. In the first part of the text we are dealing with, these children are described as sucking the breasts of Atirat, El's wife, and of Rahmay, "the one with the womb" or "the pregnant one", undoubtedly a hypostasis of Atirat, personifying the pregnancy of the Mother of the Gods. It is almost certain, therefore, that the two unnamed women represent Atirat and her double Rahmay. Now, in the texts from Ugarit, Atirat's full name is given as 'Atirat yammi, "Atirat of the sea" or even "the one treading on the sea"27. Consequently, the goddess seems to be related to the sea, and so do the two women of our text.

At this point, it would be tempting to refer to the Near Eastern representations of two goddesses with "flowing vases" 28 or to the "naked woman" with streams of water flowing from her shoulders ${ }^{29}$. One could even refer to the birth of Aphrodite from the sea, and eventually quote Hesiod's popular etymology of her name, derived

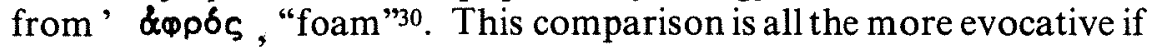
we consider that Aphrodite is precisely a goddess of birth and fertility, and often seems to be little more than the personification of sexual instincts.

Whatever the relationship between Aphrodite and the two women of the Ugaritic text, the narrative relates that, at their sight, the god El's manhood was aroused despite the fact that in other texts, probably later ones, he is described as an old man with white hair ${ }^{31}$. His organ becomes "as long as the sea", perhaps a designation of the cultual basin, like the one in Solomon's temple, and not of the Mediterranean sea or of a mythological Ocean. Still, if we consider that the given diameter of the "sea" in Solomon's temple amounts to $5 \mathrm{~m}$ and that the first stone basin from Amathus measures $3.19 \mathrm{~m}$ in diameter, the 
picturesque expression of the Ugaritian poet gives $\mathrm{El}$ a Priapic phallus indeed. The supreme god El brings the two women to his house, continues the narrative, - then he shoots down a bird, he plucks it and sets it to roast on the fire. Undoubtedly, this action symbolizes a rite of sympathetic magic supposed to heal impotence, as in Babylonian rituals $^{32}$, or at least to induce the two women to make love with El. While the bird browns on the coal, magically inflaming the two women with passion for $\mathrm{El}$, an ominous formula, introduced by the verb pat $\hat{u}$, "to charm" or "to bewitch", rather than "to seduce" or "to entice", is "recited by a priest in explanation of the action" 33 : "If the two women cry out 'O sir, $\operatorname{sir}(m u t u)$ ',,.. the two women are wives of El... But if the two women cry out 'O daddy, daddy ('adda)',...the two girls are daughters of El..."

Now, once the bird has browned, the two women cry out "O sir, sir", as was to be expected, and become El's wives. The term mutu, in fact, is ambivalent and can mean either "man", "sir", or "husband".

Then El bends over the two women and, after he has laid with them, they conceive and give birth to two children called Shachar and Shalim, "Dawn" and "Sunset".

Then El embraces the two women again, repeating the process of copulation several times, and they conceive the "gracious gods". According to most authors ${ }^{34}$, a rubric states at this point that the passage in question should be recited up to five times, viz: "He stooped, kissed their lips. Behold! their lips were sweet. While (he was) kissing, there was conception; while (he was) embracing, there was orgasm".

The newly born deities had an enormous appetite. They searched and hunted for food until they came upon "the guardian of the sownland", who let them enter the fields sown with corn and the orchards planted with vines. There they found the food and the wine they needed. Undoubtedly, this part of the text constitutes the peak of the narrative and the materialization of the results expected from the performed ritual.

However, the question is whether we are really dealing here with a sacred play or "ritual pantomime", or only with a hieros $\log o s$, a mythological account read by a priest. The rubrical passage prescribing the five-fold recitation of the section that describes El's love-making and the songs to be sung by the assembly would seem to leave enough time for a cultic action to take place, eventually for the sacred marriage to be performed at this moment. Then the narrator 
continues and announces: "Both of them were in labour and gave birth, they gave birth to the gracious gods".

If we admit that the sacred marriage was actually performed at that moment, it is likely for the god El to have been represented by the king of Ugarit ${ }^{35}$.

This eventuality seems to be suggested by the Sumerian parallels ${ }^{36}$ and by the role played by the Assyrian king in the ritual of the New Year festival, as well as by the epithet of "king" often apposed to El's name in mythological texts from Ugarit ${ }^{37}$. In fact, the king of Ugarit was present at the ceremony and he is greeted in the first part of the text (line 7).

It is more difficult to say who represented the two women mentioned in the text. It has been assumed that the queen and a high priestess, probably a princess, played this role. However, this is by no means certain, and the two women - supposed also to cry out "Father, Father" or "Mother, Mother" - could quite as well have been young hierodules, like the Babylonian naditu-priestesses who entered the cloister upon reaching their puberty; they were regarded as the wives of their god and were initiated at his festival.

Since the narrative part of the text culminates in quenching with wine the thirst of the gracious gods and since wine played such an important role in the celebration of the New Year festivities, it is likely that the sacred marriage was followed by a banquet, to which only a limited number of initiated persons was allowed to participate. The mention of wine, the allusion to hydrophory, and some other elements which go beyond the scope of the present paper, indicate that the celebration took place in autumn and aimed at providing the autumnal rain-like dew and the winter rainfalls which were of vital importance to the sown soil and to Syrian agriculture in general.

A probable allusion to the king's sacred intercourse with the representative of a goddess is attested also in another ritual text found at Ugarit ${ }^{38}$. This text, however, is more recent and the hierodule personifies there the goddess Astarte-at-the-window ${ }^{39}$. There seems to be no connection between this later text and the more ancient ritual dealt with in this paper. 


\section{Notes}

1 An annotated bibliography of works pertaining to this text, down to 1971 , can be found in D.T. Tsumura, The Ugaritic Drama of the Good Gods - A Philological Study, dissert. Brandeis University 1973, pp. 228-239. Another overview is given by R.J. Clifford, Recent Scholarly Discussion of CTCA 23 (UT 52), SBL Seminar Papers 1 (1975), pp. 99-105. At least the main recent translations have to be added: J.C. de Moor, New Year with Canaanites and Israelites, Kampen 1972, Vol. I, pp. 6-8: Vol II, pp. 17-24; A. Caquot - M. Sznycer - A. Herdner, Textes ougaritiques I. Mythes et légendes, Paris 1974, pp. 353-379; J.C.L. Gibson, Canaanite Myths and Legends, Edinburgh 1978, pp. 28-30 and 123-127; G. Del Olmo Lete, Mitos y leyendas de Canaan, Madrid 1981, pp. 427-448.

- 2 Thus G.R. Driver, Canaanite Myths and Legends, Edinburgh 1956, p. 23b. Cf. Th. H. Gaster, Thespis, 2nd. ed., Garden City, N.Y., 1961, pp. 406-417.

3 On El's abode, see E. Lipiński, El's Abode: Mythological Traditions related to Mount Hermon and to the Mountains of Armenia, Orient. Lov. Per. 2 (1971), pp. 13-69, here in particular pp. 65-69.

4 Lines 30-31.

5 The term $g p$ used here is related to Arabic gauf, "hollow, cavity, depression". Cf. E. Lipiński, La royauté de Yahwé dans la poésie et le culte de l'ancien Israël, 2nd ed., Brussels 1968, p. 205, n. 3.

6 Herodotus, Histories IV, 85, where the expression is applied to the Aegean Sea.

7 Lucian, The Syrian Goddess 13.

8 Pausanias, Description of Greece, I, 18, 7.

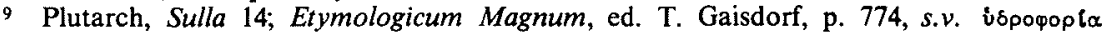
Hesychius, Lexicon, s. v. ús poøop la

10 The "great chasm" of the Greek literature, $\chi_{\alpha}^{\alpha} \sigma \alpha \alpha \mu \varepsilon_{\gamma \alpha}$ (Hesiod, Theogony 740), was Tartarus. Euripides, The Phoenician Maidens, 1604-1605, speaks even of the "bottomless

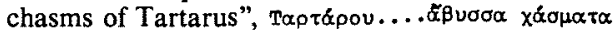

11 Plutarch, Sulla 14.

12 Compare the Scholiasts on Aristophanes, Acharnians 1076, and on Frogs 218.

13 Mishnah, Sukkah IV, 9. Cf. N.H. Snaith, The Jewish New Year Festival. Its. Origin and Development, London 1947, pp. 85-88. The practice would go back to the First Temple period according to R. Dussaud, Les origines cananéennes du sacrifice israélite, Paris 1921, pp. 203207; id., Les découvertes de Ras Shamra (Ugarit) et l'Ancien Testament, Paris 1937, p. 74.

14 J.G. Frazer, The Golden Bough, one vol. ed., London 1923, pp. 63-83.

is See C.C. Wylie, On King Solomon's Molten Sea, Biblical Archaeologist 12 (1949), pp. 86-90; M. Noth, Könige I (BKAT IX/1), Neukirchen-Vluyn 1968, pp. 155-156. The motif of the "bronze sea" in art history has been studied by M. Trokay, Compositions monumentales du Proche-Orient ancien et représentations mosanes de fonts baptismaux, Clio et son regard. Mélanges d'histoire, d'histoire de l'art et d'archéologie offerts à Jacques Stiennon, Liège 1982, pp. 639-652. I owe this reference and the ones of the following two notes to the kindness of Dr Robert Laffineur, University of Liège, whom I warmly thank.

16 A. Hermary, Amathonte II. Testimonia, deuxième partie: les sculptures découvertes avant 1975, Paris 1981, pp. 83-84, pl. 19-20, no. 81, with earlier literature. One could add to it A. Parrot, Le temple de Jérusalem, Neuchâtel 1954, p. 34.

17 P. Aupert, etc., Rapport sur les travaux de la mission de l'École française à Amathonte en 1976, $B C H 101$ (1977), pp. $781-815$ (see pp. 800-803): id. - A. Hermary, etc., Rapport sur les travaux de la mission de l'École française à Amathonte en 1979, $B C H 104$ (1980), pp. 805-822 (see p. 806, plan of fig. 1); id-id., Amathonte: Rapport préliminaire sur les travaux de l'École française d'Athènes (1975-1979), RDAC 1980, pp. 217-238, pl. XXV-XXIX (see pp. 231-238 referring to the sanctuary of $\mathbf{\Sigma} u \pi p(\alpha)$; A. Hermary, Les fouilles de la Mission française à Amathonte (1980-1983), RDAC 1984, pp. 265-277 and pl. LX-LXII (see pp. 269-276), According to the accounts of 19 th century travellers, scattered fragments of the second basin were visible on the acropolis of Amathus at the time when the first basin was taken away and transported to the Musée de Louvre. These generally anecdotic reports have been collected in P. Aupert - M.-Ch. Hellmann, Amathonte I. Testimonia, première partie, Paris 1984.

18 G. Perrot - Ch. Chipiez, Histoire de l'art dans l'antiquité III, Phénicie, Cypre, Paris 1885, p. 281 , fig. 212 , of unknown provenience. 
19 L. Palma di Cesnola, Cyprus: Its Ancient Cities, Tombs, and Temples, London 1877, pp. I44145; J.L. Myres, Handbook of the Cesnola Collection of Antiquities from Cyprus, New York 1914, no. 1863; O. Masson, Les inscriptions chypriotes syllabiques, Paris 1961, no. 291, pl. 51, 1. A similar vessel was found next to the northern wall of the temple of Golgoi: L. Palma di Cesnola, op. cit., p. 145; J. Doell, Die Sammlung Cesnola (Mémoires de l'Académie de S. Pétersbourg VII, sér. XIX, no. 4, 1873), S. Pétersbourg 1873, pl. XIII, 11; J.L. Myres, op. cit., no. 1380 .

20 B. Soyez, Note sur le culte du vase en Syrie, Berytus 24 (1975-76), pp. 43-45.

21 B. Soyez, L'adoration de l'urne (à propos d'un sarcophage sidonien du Musée d'Istanbul), MUSJ 49 (1975-76), pp. 543-547, pl. I.

22 These ritual "seas" may have prompted comparisons like those in the Etana Epic, where Etana tells the eagle that "the wide sea is just like a tube" or "like a bread basket"; cf. $A N E T^{3}, \mathrm{p}, 118 \mathrm{~b}$.

${ }^{23} E A 29,24$. The usual Akkadian construction is sutēlû ana, "to reach as high as" $(C A D, \mathrm{E}$. p. 135b), which corresponds exactly to Ugaritic $s t l y l$.

24 They are resumed by D.T. Tsumura, The Ugaritic Drama of the Good Gods, pp. 60-63, with a conclusion based on a wrong interpretation of 'agannu.

25 The comparison drawn by J.R. Porter, Genesis XIX: 30-38 and the Ugaritic Text of ŠHR \& ŠLM, Proceedings of the Seventh World Congress of Jewish Studies. Studies in the Bible and the Ancient Near East, Jerusalem 1981, pp. 1-8, between the two women in KTU23 and the two daughters of Lot in Gen. 19, 30-38 does not really help us in understanding either the biblical tale or the Ugaritic myth.

26 E. Laroche, Glossaire de la langue hourrite, $R H A 34,1976$, p. 37, referring to $K U B$ XLV, 47, III, 6 and IV, 17.

27 Compare W.F. Albright, Yahweh and the Gods of Canaan, London 1968, p. 105.

28 A. Parrot, Mission archéologique de Mari, Vol. II/2 (BAH 69), Paris 1958, pl. X-XI; Vol. II/3 (BAH 70), Paris 1959, pl. IV-VI; The Cambridge Ancient History. Plates to Vol. Iand II, new ed., Cambridge 1977, pl. 66.

29 F. Digard, Répertoire analytique des cylindres orientaux, Paris 1975, no. 4452; U. Winter, Frau und Göttin (OBO 53), Freiburg-Göttingen 1983, fig. 126.

30 Hesiod, Theogony 188-206.

31 KTU 1. 3, V, 2. 24-25; 1. 4, V, 4; 1. 18, I, 11-12 = CTA 3, E, 10. 32-33; 4, V, 66; 18, I, 11-12.

32 R.D. Biggs, SA.ZI.GA. Ancient Mesopotamian Potency Incantations (TCS 2), Locust Valley 1967 , pp. $49 f f$.

33 Thus Th. H. Gaster, An Ancient Semitic Mystery-Play, SMSR 10 (1934), pp. 156-164 (see p. 156).

34 Despite some interesting observations, we cannot agree with the recent attempt by D.T. Tsumura, Ritual Rubric or Mythological Narrative? - CTA 23(UT 52): 56-57 Reconsidered, Proceedings of the Seventh World Congress of Jewish Studies. Studies in the Bible and the Ancient Near East, Jerusalem 1981, pp. 9-16, who tried to explain these lines as part of the mythological narrative. See already id., The Ugaritic Drama of the Good Gods, pp. 78-81. In particular, Tsumura's translation of phr kl'at as "total completion" ascribes an unattested meaning to the Ugaritic words, and the term yrh, "month", does not appear in the text, as would be expected if El was to count the months of pregnancy. Compare $K T U 117$, II, 43-44= CTA 17, II, 43-44 and W.G. Lambert - A.R. Millard, Atra-hasis, Oxford 1969, p. 62, lines 278281.

35 See already $R$. Dussaud, Les Phéniciens au Négeb et en Arabie d'après un texte de Ras Shamra, RHR 108 (1933), pp. 5-49, in particular pp. 10-11: "Il peut s'agir simplement de prostitution sacrée, comme Lucien le prétend pour Byblos, mais aussi de rites plus solennels caractérisés par l'intervention du dieu lui-même ou du roi divinisé qui s'unit à la déesse de la féconditè", the goddess represented then by "la grande prêtresse".

36 J. van Dijk, La fête du nouvel an dans un texte de Sulgi, BiOr 11 (1954), pp. 83-88; W.H. Ph. Römer, Sumerische 'Königshymnen' der Isin-Zeit, Leiden 1965, pp. 128-208; S.N. Kramer, The Sacred Marriage Rite, Bloomington 1969; J. Renger - J.S. Cooper, Heilige Hochzeit, $R L A$ IV, Berlin - New York 1972-75, pp. 251-269. Compare also the later Tyrian ritual: E. Lipiński, La fête de l'ensevelissement et de la résurrection de Melqart, Actes de la XVIIe Rencontre Assyriologique Internationale, Ham-sur-Heure 1970, pp. 30-58. 
37 W. Schmidt, Königtum Gottes in Ugarit und Israel (BZAW 80), Berlin 1961, pp. 18-20.

$38 K T U 1.43=C T A 33$, in particular lines 1-2.

39 E. Lipiński, Vestiges phéniciens d'Andalousie, Orient. Lov. Per. 15 (1984), pp. 81-132 and pl. XI-XV (see p. 115-116).

\section{Summary}

The sacred marriage was the main manifestation of the fertility cult in Ugarit, as well as in the other regions of the ancient Near East. The authors assuming that this rite was performed by the King at the close of the New Year festivities, base themselves on the mythological and ritual text $K T U 1.23$, allegedly a libretto of a cultic play in which the roles of Head of the Pantheon, El, and of his wife, Atirat, were played by the King and the Queen of Ugarit. A series of preparatory rites took place before the sacred marriage, which constituted the peak of the ceremony. The offspring born from this union were called the "gracious gods".

The aim of this contribution is to comment upon the above mentioned composition, of which different interpretations have been given, and to determine to what extent it can be considered a reliable basis for the study of the fertility cult in Ugarit. The sacred marriage reported by a hieros logos or even performed in a sacred play, the allusions to hydrophory, which aims at providing dew and rainfalls, and the mention of wine, that played an important part in the New Year festivities, constitute indeed various aspects of a fertility ritual enacted in autumn. 


\section{Résumé}

Le mariage sacré était l'expression privilégiée du culte de fertilité à Ugarit comme dans les autres régions de l'ancien Proche-Orient. On suppose que ce rite était accompli par le roi à la fin des festivités du Nouvel An et on se réfere, en l'occurrence, au texte mythologique et rituel $K T U 1.23$, qui contiendrait le scénario d'un drame cultuel dans lequel le roi jouait le rôle du dieu $\mathrm{El}$, le chef du panthéon, et la reine, celui de la déesse Atirat, la parèdre de El. Divers rites préparatoires auraient précédé le mariage sacré qui devait constituer l'apogée de la cérémonie. Les enfants nés de cette union portaient le nom de "dieux grâcieux".

Le but de la présente contribution est de commenter le texte en question, dont on a proposé diverses interprétations, et de voir dans quelle mesure il peut servir de base à l'étude du culte de fertilitè à Ugarit. Le mariage sacré, relaté dans un hieros logos ou accompli sous la forme d'un drame sacré, les allusions au rite d'hydrophorie destiné à provoquer une rosée abondante et des chutes de pluie, la mention du vin, qui jouait un rôle important lors des fêtes du Nouvel An, voilà autant d'aspects divers d'un rituel de fertilité qui devait effectivement être mis en oeuvre au début de l'automne. 